\title{
The Evaluation Of Cytotoxicity And Anti- Inflammatory Effects Of Selected South African Medicinal Plants Against C2c12 Cells And Raw 264.7 Cells
}

\author{
Nkala, B.A, ${ }^{\mathrm{a}}, *$, Mbongwa, H.P. ${ }^{\mathrm{a}}$, Qwebani-Ogunleye, T $^{\mathrm{b} .}$ \\ ${ }^{a}$ Department of Human Physiology, School of Laboratory Medicine and Medical Sciences, College of Health Sciences, University of KwaZulu- \\ Natal, Durban, 4001, South Africa \\ * corresponding author, Email: bee.nkala81@gmail.com (Nkala, B.A.) \\ bInstitute of Traditional Medicine and Traditional Knowledge, Vaal University of Technology Science and Technology Park, 5 Moshoeshoe Road, \\ Sebokeng, 1911, South Africa.
}

DOI: 10.29322/IJSRP.10.02.2020.p9830

http://dx.doi.org/10.29322/IJSRP.10.02.2020.p9830

\begin{abstract}
Medicinal plants are used in traditional medicine throughout the world. In addition to this, certain communities consider medicinal plants to be safer than drugs and able to treat more than one ailment. This study aimed to evaluate the cytotoxicity and anti-inflammatory effects of Euclea crispa (leaf), Eulea natalensis (leaf), Schkuhria pinnata (leaf), Ziziphus mucronata (leaf), Ziziphus mucronata (fruits), Lippia javanica (leaf), Vernonia oligocephala (leaf), Clerodendrum myricoides (leaf), and Erythrina lysistemon (leaf) in C2C12, and RAW 264.7 cells. Plants were extracted with $90 \%$ methanol $(1 \mathrm{~g} / 10 \mathrm{ml})$ and diluted in distilled water to give a final concentration of $10 \mathrm{mg} / \mathrm{ml}$. C2C12, and RAW 264.7 cells were treated for $24 \mathrm{~h}$ with various concentrations of plant extracts $(10-1000 \mu \mathrm{g} / \mathrm{ml})$. Cytotoxicity was evaluated with Alamar Blue and crystal violet cell viability assays. RAW 264.7 cells were stimulated with lipopolysaccharide (LPS) to produce nitric oxide (NO). Thereafter, the antiinflammatory effect of the plant extracts was assessed by their ability to inhibit NO production, using the Griess reagent assay. None of the plants extracts demonstrated cytotoxic effects at the concentrations used against RAW 264.7 cells with $\mathrm{LC}_{50}$ value $>1000 \mu \mathrm{g} / \mathrm{ml}$. However, a degree of cytotoxicity in all plant extracts against $\mathrm{C} 2 \mathrm{C} 12$ cells in higher concentrations was observed with $\mathrm{LC}_{50}<1000 \mu \mathrm{g} / \mathrm{ml}$. All plant extracts demonstrated some degree of anti-inflammatory effect. However, plant extracts exhibited marked anti-inflammatory activities. These were Clerondendrum myricoides (35\% - 89\%), Lippia javanica (26\% $77 \%)$, Erythrina lysistemon (23\% - 76\%), Schkuhria pinnata $(27 \%$ - 65\%), and Vernonia oligocephala (16\% - 58\%) with IC50 value $>1000 \mu \mathrm{g} / \mathrm{ml}$. The present findings suggest that these plants' extracts may serve as a promising therapeutic agent for inflammatory diseases and authenticates their use in traditional medicine.
\end{abstract}

Index Terms- Cytotoxicity, Cell viability, Medicinal plants, antiinflammatory, inhibition.

\section{INTRODUCTION}

$\mathrm{M}$ edicinal plants are widely utilized in traditional medicine throughout the world (Deutschländer et al., 2009; Yuan et al., 2016). Essentially, certain communities consider medicinal plants to be safer than drugs, and able to treat more than one ailment (Pan et al., 2013; Sofowora et al., 2013). The selected South African plants have been reported for the treatment of numerous ailments by the traditional healers. The plants of interest for this study were Euclea crispa (leaf), Eulea natalensis (leaf), Schkuhria pinnata (leaf), Ziziphus mucronata (leaf), Ziziphus mucronata (fruits), Lippia javanica (leaf), Vernonia oligocephala (leaf), Clerodendrum myricoides (leaf), and Erythrina lysistemon (leaf) (Nkala et al., 2019a). The present study seeks to validate the usefulness of these medicinal plants by traditional healers.

Essentially, Euclea crispa (leaf) has been reported to be used to treat stomach disorders, measles, coughs, constipation, diabetes, rheumatism, and epilepsy (Raimondo et al., 2009). Deutschländer et al., (2009) described the use of Eulea natalensis in a variety of traditional remedies for worms, stomach disorders, toothache, headache, chest complaints, pleurisy, urinary tract infections, venereal diseases, schistosomiasis, dysmenorrhoea, scrofulous swellings, abnormal growths on skin, leprosy, and diabetes (Maroyi, 2017). Schkuhria pinnata has been reported to be useful as a bactericide in open wounds, to treat acne, malaria, inflammation, as a blood purifier, diuretic, and treatment of diabetes (Bussmann et al., 2008; Deutschländer et al., 2009). Ziziphus mucronata has been used for the treatment of boils, swollen glands, wounds, sores, and diabetes (Deutschländer et al., 2009; Ibrahim and Islama, 2017). Interestingly, Lippia javanica has been used to disinfect meat that has been contaminated by anthrax (Van Wyk, 2011). In traditional medicine, Lippia javanica has been used for the treatment of diabetes, fever, cough, bronchitis, and influenza (York, 2012; Arika et al., 2016). Vernonia oligocephala has been used for the relief of stomach ache, and the treatment of diabetes (Amusan et al., 2007). Clerodendrum myricoides has been reported to be used for snakebites, to reduce bodily swellings, relieve indigestion, to treat 
colds, chest pains, headaches, as well as being applied to bleeding gums, and to treat impotence (Raimondo et al., 2009). Erythrina lysistemon has been reported to be used for the treatment of sores, wounds, abscesses, arthritis, and to relieve earache (Farag et al, 2016).

Essentially, medicinal plants needed to be validated for safety, to ensure that they are not cytotoxic. The cytotoxicity profiling of these plant species plays an important role to support their use in the medicinal plants' practice. The cell-based assay is often the preferred method of screening for cytotoxicity in various cell lines, including C2C12 cells, and RAW 264.7 cells (Kaur and Dufour, 2012).

The $\mathrm{C} 2 \mathrm{C} 12$ cells is a murine myoblast cell line, derived from satellite cells (Yaffe and Saxel, 1977). Essentially, myoblast becomes myocyte during myogenesis to form muscle fibers in skeletal muscles (Hyejin et al., 2017). C2C12 cells are mononucleated, fusiform structures which progressively fuse to form plurinucleate syncytia that further differentiate in culture to acquire the morpho-functional features of the muscle cells (Yaffe and Saxel, 1977; Burattini et al., 2009; Girgis et al., 2013). These cells are well-established mouse myoblast cells used widely as an in vitro model of skeletal muscle (Burattini et al, 2009; Morissette et al, 2009; Girgis et al., 2013; Hyejin et al, 2017; Musso et al., 2019). Furthermore, C2C12 cells have been used to assess the cytotoxicity effects of medicinal plants (van Huyssteen et al., 2011; Beseni et al., 2019), and also have been used for glucose regulation as to access the ability of medicinal plants to regulate glucose blood levels(Harbilas et al., 2009; Javad et al., 2011; Padmanabha and Kaiser, 2011; Beseni et al., 2019).

The RAW 264.7 cells are commonly used as a model of mouse macrophages for the study of cellular responses to microbes and their products (Berghaus et al., 2010). Hence, they have been described as an appropriate model of macrophages, and ultimately capable of performing pinocytosis and phagocytosis (Taciak et al., 2018). The cells can increase nitric oxide (NO) production when stimulated with lipopolysaccharide (LPS), and this enhances phagocytosis (Fuentes et al., 2014). RAW 264.7 cells has been widely used in medicinal plant's research with particular focus on cytotoxicity effects and anti-inflammatory effects (Soromou et al., 2012; Razali et al, 2014; Lee et al., 2017; Soonthornsit et al., 2017; Kamtchueng et al., 2017; Kudumela et al., 2018; Ayupova et al., 2019). The ability of plant extracts to inhibit macrophage functions by decreasing the production of inflammatory mediators such as NO, prostaglandins, and cytokines has been observed (Jo et al., 2010). The potential of plant extracts to inhibit NO production in tissue culture medium has been reported (Lee et al., 2010). This study aimed to evaluate the anti-inflammatory effects of the plant extracts in lipopolysaccharide (LPS)-stimulated RAW 264.7 cells. Besides, the cytotoxicity effects of the plant extract against $\mathrm{C} 2 \mathrm{C} 12$ cells, and RAW 264.7 cells was evaluated.

\section{MATERIALS AND METHODS}

\subsection{Collection and extraction}

Plant species $(n=9)$ were collected from Walter Sisulu National Botanical Gardens, South Africa, in February 2017 (Table 1 ). The voucher specimens are held at Walter Sisulu National Botanical Gardens herbarium. The plant material was air- dried in a well-ventilated room. After drying, the plants were ground into a powder and stored away from light at room temperature.

Table 1: Accession numbers and voucher specimen numbers of the nine plant species used in this study.

\begin{tabular}{|c|c|c|c|c|c|}
\hline \multirow[t]{2}{*}{ NAME } & \multirow[t]{2}{*}{$\begin{array}{l}\text { FAMIL } \\
\text { Y }\end{array}$} & \multirow[t]{2}{*}{$\begin{array}{l}\text { PA } \\
\text { RT }\end{array}$} & \multirow{2}{*}{$\begin{array}{l}\text { Access } \\
\text { ion } \\
\text { nUMB } \\
\text { ER }\end{array}$} & \multicolumn{2}{|c|}{$\begin{array}{l}\text { VOUCHER OF } \\
\text { SPECIMEN } \\
\text { COLLECTED }\end{array}$} \\
\hline & & & & Date & $\begin{array}{l}\text { NUMB } \\
\text { ER }\end{array}$ \\
\hline $\begin{array}{l}\text { Euclea } \\
\text { crispa }\end{array}$ & $\begin{array}{l}\text { Ebenace } \\
\text { ae }\end{array}$ & Leaf & $\begin{array}{l}24 / 198 \\
2\end{array}$ & $\begin{array}{l}11 / 10 / 1 \\
982\end{array}$ & $\begin{array}{l}24, \\
\text { Behr, } \\
\text { C.M }\end{array}$ \\
\hline $\begin{array}{l}\text { Euclea } \\
\text { natalensis }\end{array}$ & $\begin{array}{l}\text { Ebenace } \\
\text { ae }\end{array}$ & Leaf & $\begin{array}{l}178 / 19 \\
87\end{array}$ & $\begin{array}{l}10 / 6 / 19 \\
87\end{array}$ & $\begin{array}{l}479 ; \\
\text { Steel, } \\
\text { B.S }\end{array}$ \\
\hline $\begin{array}{l}\text { Schkuhria } \\
\text { pinnata }\end{array}$ & $\begin{array}{l}\text { Asterace } \\
\text { ae }\end{array}$ & Leaf & N/A & N/A & N/A \\
\hline $\begin{array}{l}\text { Ziziphus } \\
\text { mucronat } \\
\text { a }\end{array}$ & $\begin{array}{l}\text { Rhamna } \\
\text { ceae }\end{array}$ & Leaf & $\begin{array}{l}36 / 198 \\
2\end{array}$ & $\begin{array}{l}15 / 10 / 1 \\
982\end{array}$ & $\begin{array}{l}39 ; \\
\text { Behr, } \\
\text { C.M }\end{array}$ \\
\hline $\begin{array}{l}\text { Ziziphus } \\
\text { mucronat } \\
a\end{array}$ & $\begin{array}{l}\text { Rhamna } \\
\text { ceae }\end{array}$ & $\begin{array}{l}\text { Fruit } \\
\mathrm{S}\end{array}$ & $\begin{array}{l}36 / 198 \\
2\end{array}$ & $\begin{array}{l}15 / 10 / 1 \\
982\end{array}$ & $\begin{array}{l}\text { 39; } \\
\text { Behr, } \\
\text { C.M }\end{array}$ \\
\hline $\begin{array}{l}\text { Lippia } \\
\text { javanica }\end{array}$ & $\begin{array}{l}\text { Verbena } \\
\text { ceae }\end{array}$ & Leaf & $\begin{array}{l}16 / 201 \\
4\end{array}$ & $\begin{array}{l}22 / 1 / 20 \\
14\end{array}$ & $\begin{array}{l}28 ; \\
\text { Kondlo } \\
\text { M }\end{array}$ \\
\hline $\begin{array}{l}\text { Vernonia } \\
\text { oligoceph } \\
\text { ala }\end{array}$ & $\begin{array}{l}\text { Asterace } \\
\text { ae }\end{array}$ & Leaf & $\begin{array}{l}268 / 20 \\
13\end{array}$ & $\begin{array}{l}12 / 05 / 2 \\
013\end{array}$ & $\begin{array}{l}29 ; \\
\text { Hankey } \\
\text { A.J }\end{array}$ \\
\hline $\begin{array}{l}\text { Clerodend } \\
\text { rum } \\
\text { myricoide } \\
\text { s }\end{array}$ & $\begin{array}{l}\text { Lamiace } \\
\text { ae }\end{array}$ & Leaf & $\begin{array}{l}11 / 198 \\
7\end{array}$ & $\begin{array}{l}2 / 2 / 198 \\
7\end{array}$ & $\begin{array}{l}367, \\
\text { Steel, } \\
\text { B.S }\end{array}$ \\
\hline $\begin{array}{l}\text { Erythrina } \\
\text { lysistemon }\end{array}$ & Fabaceae & Leaf & $\begin{array}{l}21 / 198 \\
2\end{array}$ & $\begin{array}{l}7 / 10 / 19 \\
82\end{array}$ & $\begin{array}{l}22 ; \\
\text { Behr, } \\
\text { C.M }\end{array}$ \\
\hline
\end{tabular}

\subsection{Preparation of crude extracts for cytotoxicity assays}

The ground plant extracts (leaves, and fruits) were extracted with $90 \%$ methanol $(1 \mathrm{~g} / 10 \mathrm{ml})$ and vigorously shaken for $3 \mathrm{~h}$. The crude extracts were filtered through Whatman No.1 filter paper and dried at room temperature under a stream of cold air. The crude extracts were reconstituted in distilled water at a concentration of $10 \mathrm{mg} / \mathrm{ml}$ for all assays.

\subsection{Cell cultures}

\subsubsection{C2C12 (ATCC CRL - 1772)}

The C2C12 (ATCC CRL-1772) cell line is derived from mouse skeletal muscle; myoblasts originally derived from satellite cells from the thigh muscle of a two-month-old female $\mathrm{C} 3 \mathrm{H}$ mouse donor $70 \mathrm{~h}$ after a crush injury (Yaffe and Saxel, 1997). The cells were donated by the Department of Biotechnology at Vaal University of Technology, South Africa. The cells were cultured 
in $75 \mathrm{~cm}^{2}$ tissue culture flasks in Dulbecco's Modified Eagle's Minimum (DMEM) containing L-glutamine and supplemented with $1.0 \mathrm{mM}$ Penicillin/Streptomycin and $10 \%$ heated foetal bovine serum (FBS). Thereafter, flasks were incubated at $37^{\circ} \mathrm{C}$ in a humidified atmosphere of $5 \% \mathrm{CO}_{2}$. The medium was changed every second day until $80-90 \%$ confluent growth was reached. Thereafter, cells were trypsinised with $0.25 \%$ trypsin EDTA. Essentially, cell viability was monitored with Trypan Blue and microscopically analysed using Countess II. The total concentration of cells was $1.16 \times 10^{6}$ cells $/ \mathrm{ml}$, of which $95 \%$ were viable $\left(1.10 \times 10^{6}\right.$ cells $\left./ \mathrm{ml}\right)$. Cells $\left(5 \times 10^{4}\right.$ cells $\left./ \mathrm{ml}\right)$ were seeded into 96-well plates and cultured overnight in a humidified atmosphere of $5 \% \mathrm{CO}_{2}$ before treatment with various plant extract concentrations.

\subsubsection{RAW 264.7 (ATTCC - TIB71)}

The RAW 264.7 (ATTCC - TIB71) macrophage cell lines are monocyte/macrophage-like cells, originating from Abelson leukaemia virus-transformed cell line derived from BALB/c mice (Fuentes et al., 2014). These cells were also donated by the Department of Biotechnology at Vaal University of Technology, South Africa. The RAW 264.7 cells were cultured in $75 \mathrm{~cm}^{2}$ tissue culture flasks in Dulbecco's Modified Eagle's Medium (DMEM) containing L-glutamine and supplemented with $1.0 \mathrm{mM}$ Penicillin/Streptomycin and $10 \%$ heated foetal bovine serum (FBS). Thereafter the flask was incubated at $37^{\circ} \mathrm{C}$ in a humidified atmosphere of $5 \% \mathrm{CO}_{2}$. The medium was changed every second day until $80-90 \%$ confluent growth was reached. Thereafter, cells were trypsinised with $0.25 \%$ trypsin EDTA. Essentially, cell viability was monitored with Trypan Blue and microscopically analysed using Countess II. The total concentration was $2.40 \times 10^{6}$ cells $/ \mathrm{ml}$, of which $98 \%$ were viable $\left(2.40 \times 10^{6}\right.$ cells $\left./ \mathrm{ml}\right)$. Cells $(5$ x $10^{4}$ cells $/ \mathrm{ml}$ ) were seeded into 96 -well plates and cultured overnight in a humidified atmosphere of $5 \% \mathrm{CO}_{2}$ before treatment with various concentrations of plant extract.

\subsection{Cell viability assays}

\subsubsection{Alamar Blue cell viability assay}

Cytotoxicity was quantified using the Alamar Blue cell viability assay (Thermo Fisher), as previously described by AlNasiry et al (2007). C2C12 cells and RAW 264.7 cells were seeded with a density of $5 \times 10^{4}$ cells $/ \mathrm{ml}$ in 96-well plates and incubated in a humidified atmosphere of $5 \% \mathrm{CO}_{2}$. After $24 \mathrm{~h}$ of incubation, cells were rinsed twice with phosphate-buffered saline (Lonza), followed by the addition of $200 \mu \mathrm{l}$ of plant extracts in varying concentrations $(10,50,100,250,500,1000 \mu \mathrm{g} / \mathrm{ml}$, respectively). This was done in triplicates and the experiment was repeated three times. The plant extracts, which were dissolved in distilled water were incubated for $24 \mathrm{~h}$ in a humidified atmosphere of $5 \% \mathrm{CO}_{2}$ together with the positive control (hydrogen peroxide) and negative control (media). After the incubation period, $30 \mu 1$ of Alamar Blue was added to each well, thereafter plates were shaken and incubated for $4 \mathrm{~h}$ in the dark. Cell viability was analysed at $570 \mathrm{~nm}$ and $600 \mathrm{~nm}$ with an Epoch 2 microplate reader (BioTek). Hydrogen peroxide $\left(\mathrm{H}_{2} \mathrm{O}_{2}\right)$ was used as a positive control. The percentage of viable cells was calculated according to the equation below:

Percentage viability $=(\underline{\text { Sample absorbance }}) \times 100$

(Positive control absorbance)

\subsubsection{Crystal violet cell viability assay}

Crystal violet (CV) cell viability assay is widely used for cytotoxicity and cell viability studies with adherent cell cultures (Feoktistova et al., 2016). Essentially, CV is a triarylmethane dye that can bind to ribose type molecules such as DNA in nuclei. Interestingly, dead cells detach from cell culture plates during washing steps, and only viable cells remain attached to the dish (Feoktistova et al., 2016). For this experiment, C2C12 cells and RAW 264.7 cells were seeded in 96-well plates and incubated in a humidified atmosphere of $5 \% \mathrm{CO}_{2}$ for $24 \mathrm{~h}$. After $24 \mathrm{~h}$ of incubation, cells were rinsed twice with phosphate-buffered saline (Lonza), followed by treatment with $200 \mu \mathrm{l}$ of plant extract at varying concentrations $(10,50,100,250,500,1000 \mu \mathrm{g} / \mathrm{ml}$ respectively). This was done in triplicates and repeated three times. The plant extracts, which were dissolved in distilled water, were incubated for $24 \mathrm{~h}$ in a humidified atmosphere of $5 \% \mathrm{CO}_{2}$ together with the positive control (hydrogen peroxide), untreated cells and negative control (media). After the incubation period, cells were washed twice with phosphate-buffered saline (Lonza). After washing, $50 \mu \mathrm{l}$ of crystal violet staining was added to all wells and plates were shaken for 20 min with Micro shake, ELISA Plate Shaker. Thereafter, plates were washed under running water and left to stand overnight to drain excess water before reading. The cell biomass was suspended in $70 \%$ ethanol and shaken for 20 minutes before analysis of cell viability at $570 \mathrm{~nm}$ and $600 \mathrm{~nm}$ using an Epoch 2 microplate reader (BioTek). Hydrogen peroxide $\left(\mathrm{H}_{2} \mathrm{O}_{2}\right)$ was used as positive control. The percentage of viable cells was calculated according to the equation here below:

Percentage viability $=\quad(\underline{\text { Sample absorbance })} \times 100$ (Positive control absorbance)

\subsection{Measurement of inhibition of nitric oxide production in LPS-stimulated RAW 264.7 cells.}

Nitric oxide (NO) released from RAW 264.7 cells was assessed using the Griess assay (Promega) as previously described by Lim et al. (2018). RAW 264.7 cells were stimulated with $3 \mu \mathrm{l}$ of lipopolysaccharide (LPS: Escherichia coli, serotype 011: B4, Sigma), and cells were seeded in 96- well culture plate at a density of $5 \times 10^{4}$ cells/well. The cells were incubated for $24 \mathrm{~h}$ under a humidified atmosphere of $5 \% \mathrm{CO}_{2}$ before treatment with various concentrations of plant extract $(10,50,100,250,500,1000 \mu \mathrm{g} / \mathrm{ml}$ respectively). This was done in triplicates and repeated three times and further incubated for $24 \mathrm{~h}$ under a humidified atmosphere of $5 \% \mathrm{CO}_{2}$ before the addition of $20 \mu \mathrm{l}$ Griess reagent. After the incubation period, $50 \mu \mathrm{l}$ of supernatant from the test culture was mixed with $50 \mu \mathrm{l}$ of Griess reagent [1\% sulfanilamide, $0.1 \% \mathrm{~N}$ 1(1-naphtyl)-ethylenediamine diehydrochloride, $2.5 \%$ phosphoric acid] followed by incubation for 10 minutes at room temperature. The optical density at $540 \mathrm{~nm}$ was measured with a microplate reader (BioTek). The results were expressed as inhibition of NO production compared to the control (LPS) using the equation below.

Percentage NO inhibition $=$

absorbance)
(Sample absorbance) x 100 (Positive LPS Control 


\section{StATISTICAL ANALYSIS}

All data were expressed as mean and standard deviation using MS Excel 2013 and ANOVA GraphPad Prism 5. Two-way repeated-measures analysis of variance (ANOVA), followed by Bonferroni posthoc test was used to analyse the data. Values were considered to be significantly different from the control if $\mathrm{p}<$ 0.0001 .

\section{RESUlTS}

\subsection{Alamar Blue cell viability}

The $\mathrm{LC}_{50}(\mu \mathrm{g} / \mathrm{ml})$ was determined after treating the cells with plant extracts $(10-1000 \mu \mathrm{g} / \mathrm{ml})$ for $24 \mathrm{~h}$ (Table 2). The plant extracts exhibited $\mathrm{LC}_{50}$ value of $<1000 \mu \mathrm{g} / \mathrm{ml}$ for all plant extracts against $\mathrm{C} 2 \mathrm{C} 12$ cells. Interestingly, the plant extracts exhibited a different $\mathrm{LC}_{50}$ value of $>1000 \mu \mathrm{g} / \mathrm{ml}$ for RAW264.7 cells. Plant extracts demonstrated cytotoxicity effects in higher concentrations for only C2C12 cells (Fig 1) and no cytotoxicity effect was observed for RAW264.7 cells (Fig 2). The untreated cells were used to establish significant difference against samples and it was observed, $\left(\mathrm{F}_{(50,198)}=41.80, \mathrm{p}<0.0001\right.$; two-way ANOVA) for C2C12 and RAW264.7 cells were $\left(\mathrm{F}_{(50,198)}=99.02, \mathrm{p}<0.0001\right.$; two-way ANOVA) (Fig 1 and Fig 2). A dose-response was observed whereby a decrease of cell viability with the increase of concentration was noted. The plant extracts were compared with the positive control $\left(\mathrm{H}_{2} \mathrm{O}_{2}\right)$ and a significant difference was observed, $\left(\mathrm{F}_{(50,198)}=41.80, \mathrm{p}<0.0001\right)$. In addition to this, untreated cells were compared with all plant extracts in all concentrations, and all plant extracts shown significant difference
$(\mathrm{F}(50,198)=41.80, \mathrm{p}<0.0001) ;$ except Erythrina lysistemon $(\mathrm{L})$ was not significantly different with untreated cells at $10 \mu \mathrm{g} / \mathrm{ml}$.

Table 2: The lethal concentration $\left(\mathrm{LC}_{50}\right)$ in $\mu \mathrm{g} / \mathrm{ml}$ and $R^{2}$ of Alamar Blue cell viability after treating with $\mathrm{C} 2 \mathrm{C} 12$ cells, and RAW 264.7 cells with plant extracts $(10-1000 \mu \mathrm{g} / \mathrm{ml})$.

\begin{tabular}{|c|c|c|c|c|c|}
\hline \multirow[t]{3}{*}{ Plant species } & \multirow{3}{*}{$\begin{array}{l}\text { Part } \\
\text { S }\end{array}$} & \multicolumn{4}{|l|}{ Cells } \\
\hline & & \multicolumn{2}{|l|}{$\mathrm{C2C12}$} & \multicolumn{2}{|c|}{ RAW264.7 } \\
\hline & & $\begin{array}{l}\mathrm{LC}_{50} \\
(\mu \mathrm{g} / \mathrm{ml})\end{array}$ & $\mathbf{R}^{2}$ & $\begin{array}{l}\mathrm{LC}_{50} \\
(\mu \mathrm{g} / \mathrm{ml})\end{array}$ & $\mathbf{R}^{2}$ \\
\hline $\begin{array}{l}\text { Euclea } \\
\text { crispa }\end{array}$ & Leaf & $\begin{array}{l}566.50 \\
2 \\
\end{array}$ & $\begin{array}{l}0.916 \\
7 \\
\end{array}$ & $\begin{array}{l}2276.46 \\
6\end{array}$ & $\begin{array}{l}0.858 \\
1 \\
\end{array}$ \\
\hline $\begin{array}{l}\text { Euclea } \\
\text { natalensis }\end{array}$ & Leaf & 454.497 & $\begin{array}{l}0.917 \\
2\end{array}$ & $\begin{array}{l}3814.95 \\
4\end{array}$ & $\begin{array}{l}0.874 \\
2\end{array}$ \\
\hline $\begin{array}{l}\text { Schkuhria } \\
\text { pinnata }\end{array}$ & Leaf & 206.079 & $\begin{array}{l}0.979 \\
7 \\
\end{array}$ & $\begin{array}{l}2458.68 \\
1\end{array}$ & $\begin{array}{l}0.953 \\
8 \\
\end{array}$ \\
\hline $\begin{array}{l}\text { Ziziphus } \\
\text { mucronata }\end{array}$ & Leaf & 150.210 & $\begin{array}{l}0.942 \\
0\end{array}$ & $\begin{array}{l}1491.55 \\
5\end{array}$ & $\begin{array}{l}0.978 \\
0\end{array}$ \\
\hline $\begin{array}{l}\text { Ziziphus } \\
\text { mucronata }\end{array}$ & $\begin{array}{l}\text { Fruit } \\
\mathrm{S}\end{array}$ & 251.699 & $\begin{array}{l}0.953 \\
4 \\
\end{array}$ & $\begin{array}{l}2582.65 \\
6 \\
\end{array}$ & $\begin{array}{l}0.945 \\
6 \\
\end{array}$ \\
\hline $\begin{array}{l}\text { Lippia } \\
\text { pinnata }\end{array}$ & Leaf & 185.906 & $\begin{array}{l}0.974 \\
4 \\
\end{array}$ & $\begin{array}{l}2477.17 \\
6\end{array}$ & $\begin{array}{l}0.930 \\
2 \\
\end{array}$ \\
\hline $\begin{array}{l}\text { Vernonia } \\
\text { oligocephala }\end{array}$ & Leaf & $\begin{array}{l}192.52 \\
4\end{array}$ & $\begin{array}{l}0.970 \\
9\end{array}$ & 210.502 & $\begin{array}{l}0.916 \\
7\end{array}$ \\
\hline $\begin{array}{l}\text { Clerodendru } \\
m \text { myricoides }\end{array}$ & Leaf & 508.834 & $\begin{array}{l}0.950 \\
3 \\
\end{array}$ & 636.916 & $\begin{array}{l}0.916 \\
7\end{array}$ \\
\hline $\begin{array}{l}\text { Erythrina } \\
\text { lysistemon }\end{array}$ & Leaf & 773.427 & $\begin{array}{l}0.964 \\
3\end{array}$ & $\begin{array}{l}1213.32 \\
7\end{array}$ & $\begin{array}{l}0.921 \\
5 \\
\end{array}$ \\
\hline $\mathrm{H}_{2} \mathrm{O}_{2}$ & & 4.382 & & 360.604 & \\
\hline
\end{tabular}




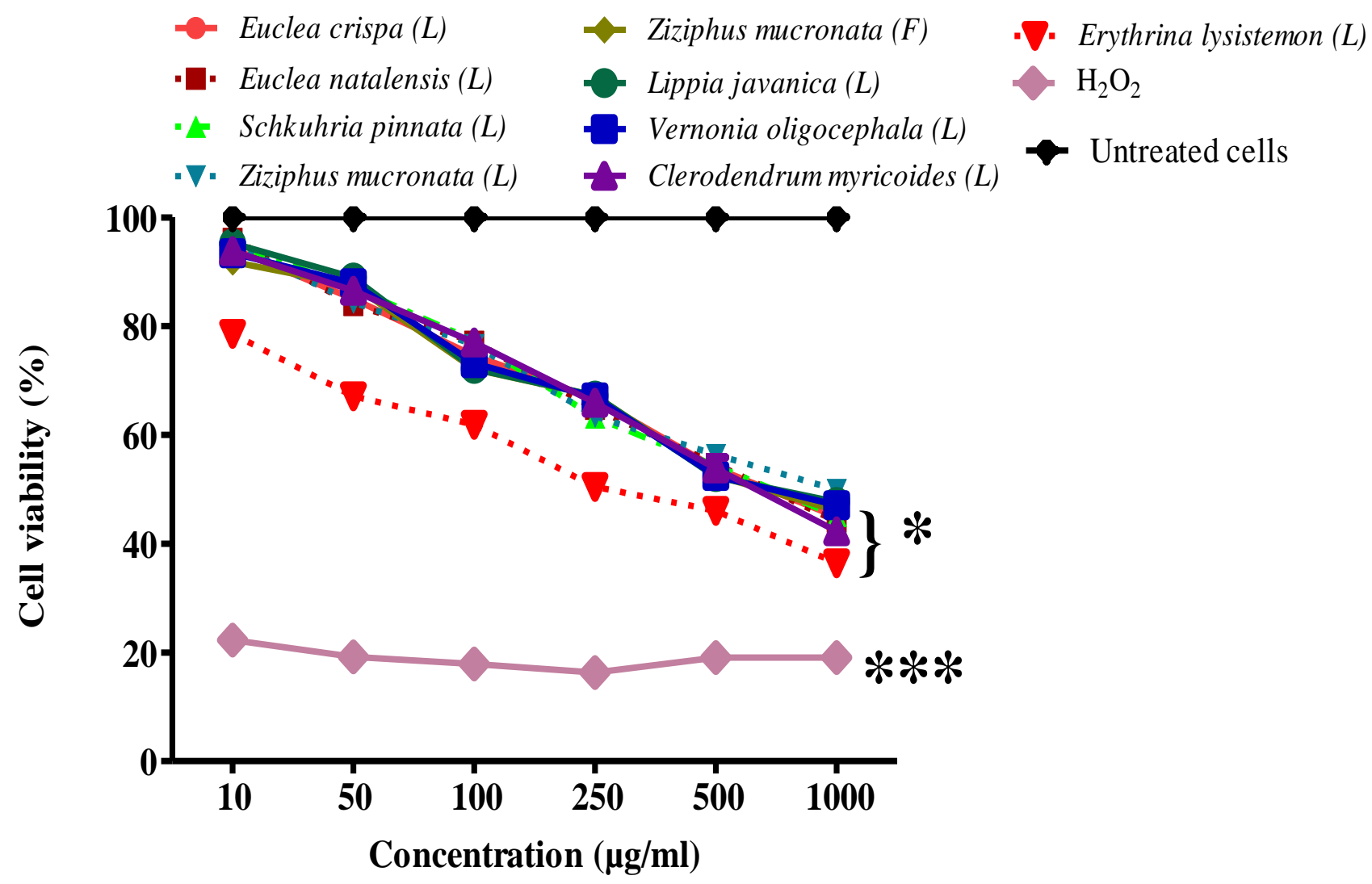

6

Figure 1: Cell viability was evaluated with the Alamar Blue assay. C2C12 cells were treated with various plant extracts $(10-1000$ $\mu \mathrm{g} / \mathrm{ml}$ ) for $24 \mathrm{~h}$. The data are presented as mean \pm S.D of triplicates experiments with similar results. (Significant treatment effect, $\mathrm{F}_{(50 \text {, }}$ ${ }_{198)}=41.80, \mathrm{p}<0.0001$; two-way ANOVA). * There is a significantly different at 10,50 , and $100 \mathrm{ug} / \mathrm{ml}$ for most plant extracts $(\mathrm{p}<$ 0.0001, Bonferroni posthoc test), except Euclea natalensis at $10 \mu \mathrm{g} / \mathrm{ml}$. *** $\mathrm{H}_{2} \mathrm{O}_{2}$ differ from untreated cells ( $<<0.0001$, Bonferroni posthoc test). 

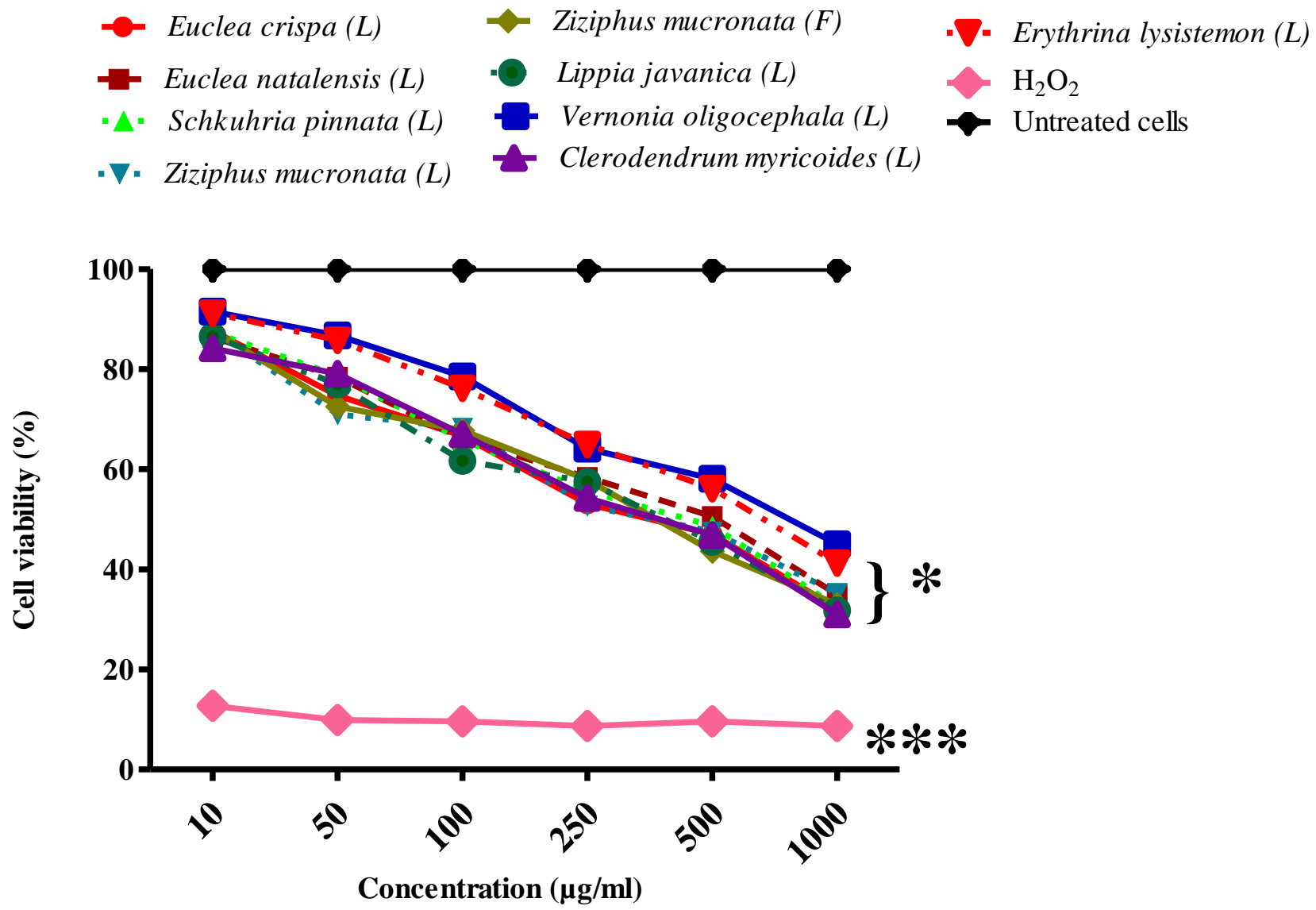

Figure 2: Cell viability was evaluated with the Alamar Blue assay. RAW 264.7 macrophages were treated with various plant extracts $(10-1000 \mu \mathrm{g} / \mathrm{ml})$ for $24 \mathrm{~h}$. The data are presented as mean \pm S.D of triplicate experiments with similar results. (Significant treatment effect, $\mathrm{F}_{(50,198)}=99.02, \mathrm{p}<0.0001 ;$ two-way ANOVA). $*$ All plant extracts significantly different from untreated cells at all concentrations ( $\mathrm{p}<0.0001$, Bonferroni posttest). *** Significant difference between $\mathrm{H}_{2} \mathrm{O}_{2}$ differ from untreated cells $(\mathrm{p}<0.0001$, Bonferroni posttest). 


\subsection{Crystal violet cell viability}

The $\operatorname{LC}_{50}(\mu \mathrm{g} / \mathrm{ml})$ was obtained after treating the cells with plant extracts $(10-1000 \mu \mathrm{g} / \mathrm{ml})$ after $24 \mathrm{~h}$ (Table 3). The crystal violet cell viability assay was used to complement the Alamar Blue cell viability assay. The cytotoxicity was observed in all plant extracts in higher concentrations with $\mathrm{LC}_{50}$ values $>700 \mu \mathrm{g} / \mathrm{ml}$ against $\mathrm{C} 2 \mathrm{C} 12$ cells (Fig 3). Similarly, no cytotoxicity was observed for plant extracts against RAW264.7 cells (Fig 4) with $\mathrm{LC}_{50}$ values $<800 \mu \mathrm{g} / \mathrm{ml}$ in all plant extracts. A dose-response was observed whereby a decrease of cell viability with the increase of concentration and cytotoxicity effect was observed in higher concentrations against $\mathrm{C} 2 \mathrm{C} 12$ cells (Fig 3). None of the plant extracts demonstrated cytotoxicity effects in all plant extracts tested against RAW 264.7 cells (Fig 4). The untreated cells were used to establish significant difference against samples and was observed, $\left(\mathrm{F}_{(50,198)}=25.82, \mathrm{p}<0.0001\right.$; two-way ANOVA $)$ for $\mathrm{C} 2 \mathrm{C} 12$ and RAW 264.7 was $\left(\mathrm{F}_{(50,198)}=99.21 ; \mathrm{p}<0.0001\right.$; twoway ANOVA). A dose-response was observed whereby a decrease of cell viability with the increase of concentration was noted.

Table 3: The lethal concentration $\left(\mathrm{LC}_{50}\right)$ in $\mu \mathrm{g} / \mathrm{ml}$ and $\mathrm{R}^{2}$ of crystal violet cell viability after treating $\mathrm{C} 2 \mathrm{C} 12$ and $\mathrm{RAW} 264.7$ cells with plant extracts $(10-1000 \mu \mathrm{g} / \mathrm{ml})$.

\begin{tabular}{|c|c|c|c|c|c|}
\hline \multirow[t]{3}{*}{ Plant species } & \multirow[t]{3}{*}{ Parts } & \multicolumn{4}{|l|}{ Cells } \\
\hline & & \multicolumn{2}{|l|}{ C2C12 } & \multicolumn{2}{|l|}{ RAW264.7 } \\
\hline & & $\mathrm{LC}_{50}(\mu \mathrm{g} / \mathrm{ml})$ & $\mathbf{R}^{2}$ & $\mathrm{LC}_{50}(\mu \mathrm{g} / \mathrm{ml})$ & $\mathbf{R}^{2}$ \\
\hline Euclea crispa & Leaf & 416.535 & 0.8756 & 764.374 & 0.8936 \\
\hline Euclea natalensis & Leaf & 649.733 & 0.9557 & 844.167 & 0.9654 \\
\hline Schkuhria pinnata & Leaf & 145.619 & 0.9803 & 314.539 & 0.9234 \\
\hline Ziziphus mucronata & Leaf & 133.374 & 0.9439 & 448.896 & 0.9187 \\
\hline Ziziphus mucronata & Fruits & 164.421 & 0.9654 & 775.017 & 0.8732 \\
\hline Lippia pinnata & Leaf & 410.436 & 0.9585 & 2115.634 & 0.9233 \\
\hline Vernonia oligocephala & Leaf & 211.676 & 0.9453 & 2754.673 & 0.8878 \\
\hline Clerodendrum myricoides & Leaf & 537.150 & 0.9726 & 1545.962 & 0.9598 \\
\hline Erythrina lysistemon & Leaf & 591.764 & 0.9787 & 866.625 & 0.9148 \\
\hline $\mathrm{H}_{2} \mathrm{O}_{2}$ & & 4.382 & & 435.076 & \\
\hline
\end{tabular}




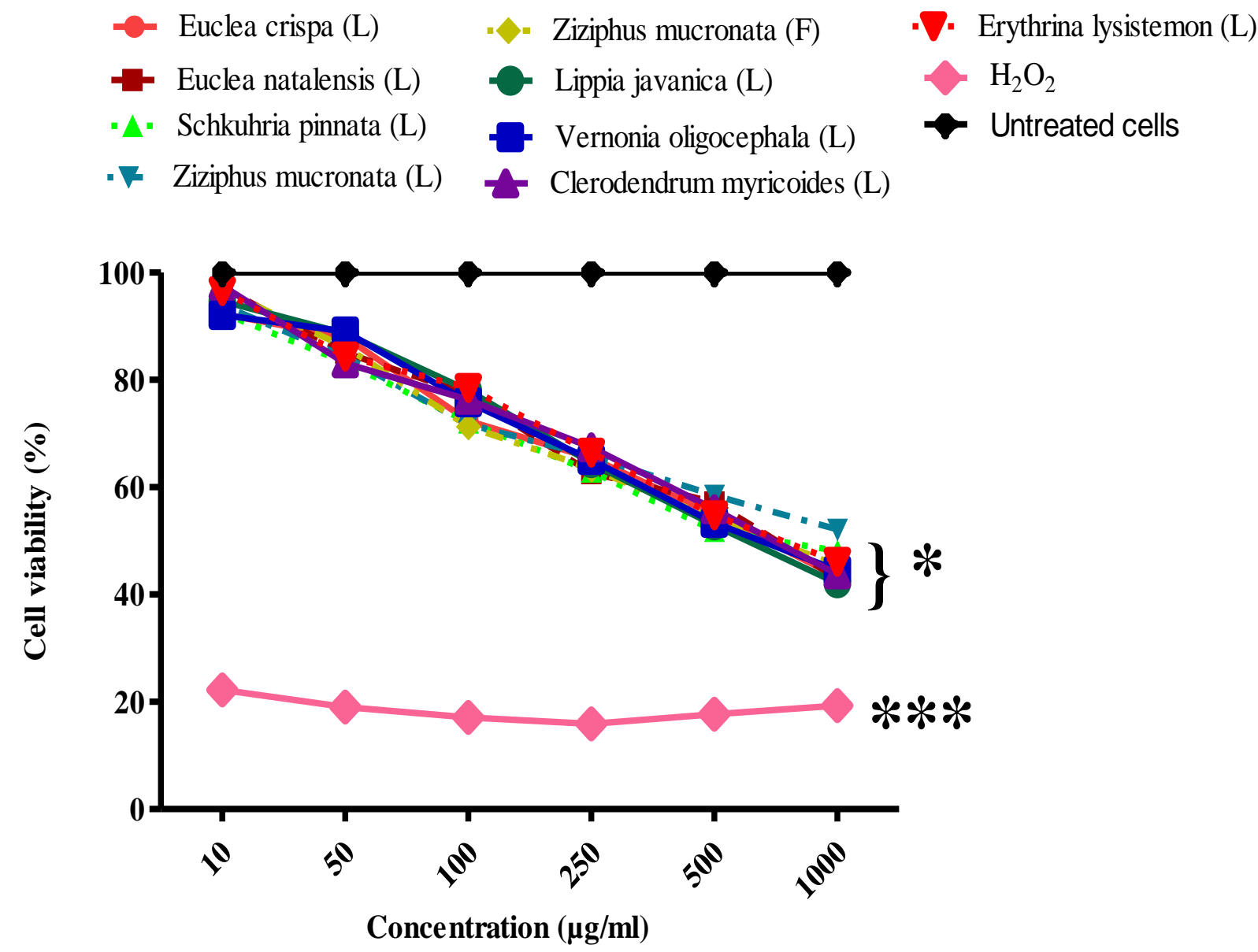

Figure 3: Cell viability was evaluated with the crystal violet assay. $\mathrm{C} 2 \mathrm{C} 12$ cells were treated with various plant extracts $(10-1000$ $\mu \mathrm{g} / \mathrm{ml}$ ) for $24 \mathrm{~h}$. The data are presented as mean \pm S.D of triplicates results. (Significant treatment effect, $\mathrm{F}_{(50,198)}=25.82$, $\mathrm{p}<0.0001$; two-way ANOVA). * All plant extracts significantly different from untreated cells at all concentrations $(\mathrm{p}<0.0001$, Bonferroni posttest), except Euclea natalensis, Lippia javanica, Clerodebdrum myricoides, and Erythrina lysistemon at $10 \mu \mathrm{g} / \mathrm{ml}$. *** Significant difference between $\mathrm{H}_{2} \mathrm{O}_{2}$ and all concentrations of plant extracts ( $\mathrm{p}<0.0001$, Bonferroni posttest). 


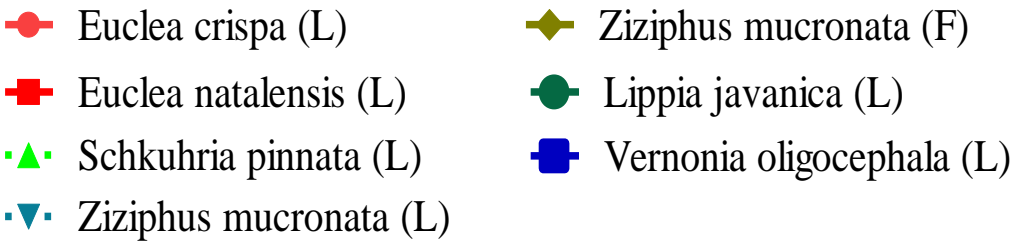

Clerodendrum myricoides (L)

Erythrina lysistemon (L)

$\mathrm{H}_{2} \mathrm{O}_{2}$

- $\nabla \cdot$ Ziziphus mucronata $(\mathrm{L})$

$\sim$ Untreated cells

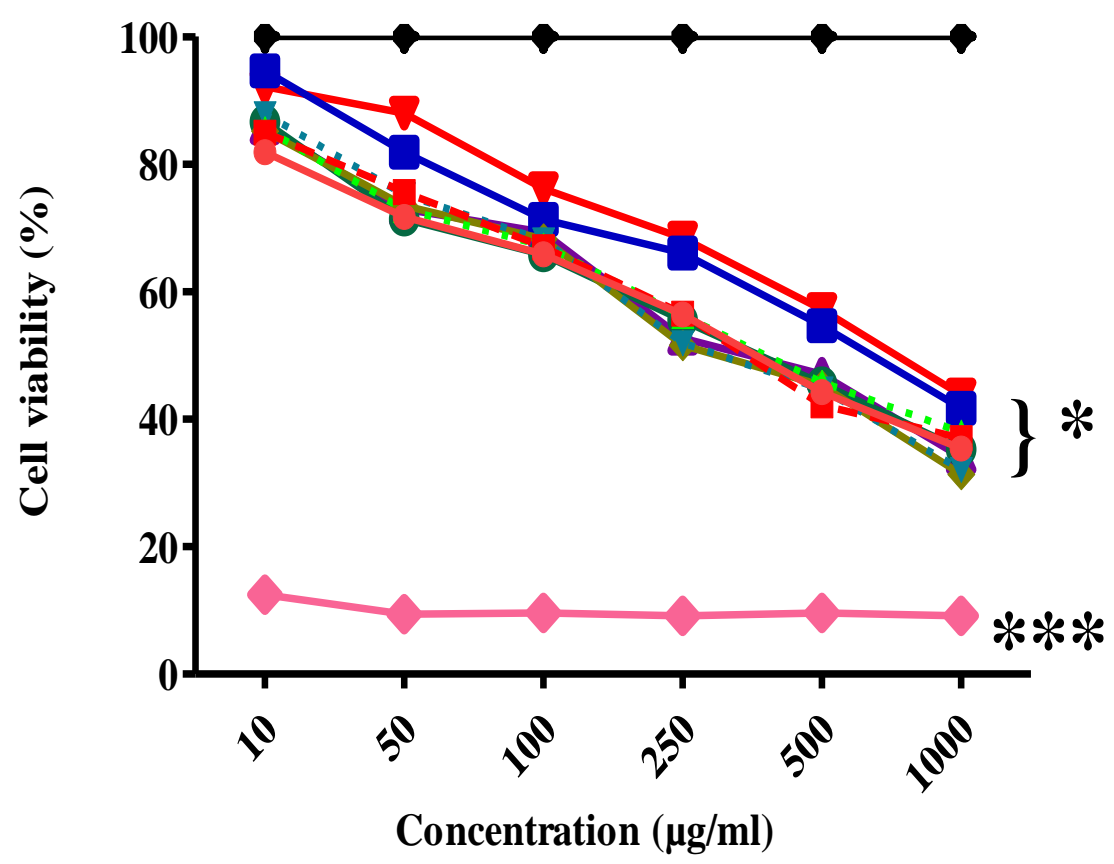

Figure 4: Cell viability was evaluated with the crystal violet assay. RAW 264.7 cells were treated with various plant extracts (10 $1000 \mu \mathrm{g} / \mathrm{ml}$ ) for $24 \mathrm{~h}$. The data are presented as mean \pm S.D of triplicate results. (Significant treatment effect, $\mathrm{F}_{(50,198)}=99.21$, $\mathrm{p}<0.0001$; two-way ANOVA). * All plant extracts significantly different from untreated cells at all concentrations $(\mathrm{p}<0.0001$, Bonferroni posttest). *** Significant difference between $\mathrm{H}_{2} \mathrm{O}_{2}$ and all concentrations of plant extracts ( $\mathrm{p}<0.0001$, Bonferroni posttest).

\subsection{Inhibition of nitric oxide (NO) production in LPS-stimulated RAW 264.7 cells.}

The concentration in $\mu \mathrm{g} / \mathrm{ml}$ at which $50 \%$ inhibition of $\mathrm{NO}$ production was achieved in inhibition concentration $\left(\mathrm{IC}_{50}\right)$ was obtained after treating RAW 264.7 cells with plant extracts $(10-1000 \mu \mathrm{g} / \mathrm{ml})$ for $24 \mathrm{~h}$ (Table 4). All plant extracts exhibited IC $\mathrm{C}_{50}$ values $>1000$ $\mu \mathrm{g} / \mathrm{ml}$, except for Schkuhria pinnata, Ziziphus mucronata (fruits), Lippia pinnata, Clerodendrum myricoides, and Erythrina lysistemon. The anti-inflammatory effect of plant extracts was evaluated after RAW 264.7 cells were stimulated with LPS to produce NO (Fig 5). Plant extracts exhibited various degrees of inhibition of NO production in a dose-dependent manner. Interestingly, the following plant extracts demonstrated a degree of NO inhibition effects. Euclea crispa (17\%- 25\%), and Eucela natalensis (4\% - 23\%) caused 50\% inhibition of NO production at 100, 250, and $500 \mu \mathrm{g} / \mathrm{ml}$. Similar effects were observed for Ziziphus mucronanta (L) (3\% - 25\%), and Zisiphus mисronota (fruits) $(3 \%-26 \%)$ at 100 , and $250 \mu \mathrm{g} / \mathrm{ml}$, respectively. In addition to this, five other plant extracts exhibited a good inhibition of NO production at higher concentrations ( $250-1000 \mu \mathrm{g} / \mathrm{ml})$, these were Clerondendrum myricoides $(35 \%-89 \%)$, Lippia javanica (26\% - 77\%), Erythrina lysistemon (23\% - 76\%), Schkuhria pinnata (27\% - 65\%), and Vernonia oligocephala (16\% $58 \%)$.

Table 4: The concentration of plant extracts that caused 50\% inhibition of NO production $\left(\mathrm{IC}_{50}\right)$ in LPS-stimulated RAW 264.7 cells.

\begin{tabular}{|l|l|l|l|}
\hline Plant species & Parts & $\mathbf{I C}_{\mathbf{5 0}}(\boldsymbol{\mu} \mathbf{g} / \mathbf{m l})$ & $\mathbf{R}^{\mathbf{2}}$ \\
\hline Euclea crispa & Leaf & 1242.366 & 0.9878 \\
\hline Euclea natalensis & Leaf & 1588.573 & 0.9533 \\
\hline Schkuhria pinnata & Leaf & 348.859 & 0.9484 \\
\hline Ziziphus mucronata & Leaf & 11949.000 & 0.9612 \\
\hline Ziziphus mucronata & Fruits & 499.600 & 0.9371 \\
\hline Lippia pinnata & Leaf & 177.902 & 0.9487 \\
\hline
\end{tabular}




\begin{tabular}{|l|l|l|l|}
\hline Vernonia oligocephala & Leaf & 2634.965 & 0.9483 \\
\hline Clerodendrum myricoides & Leaf & 707.335 & 0.9858 \\
\hline Erythrina lysistemon & Leaf & 264.287 & 0.9506 \\
\hline
\end{tabular}

- Euclea crispa (L)

-C. Euclea natalensis (L)

- Schkuhria pinnata $(\mathrm{W})$

- . Vernonia oligocephala (L)
- . Ziziphus mucronata (L)

Ziziphus mucronata $(\mathrm{F})$

Lippia javanica (L)
Clerodendrum myricoides (L)

Erythrina lysistemon (L)

Untreated cells

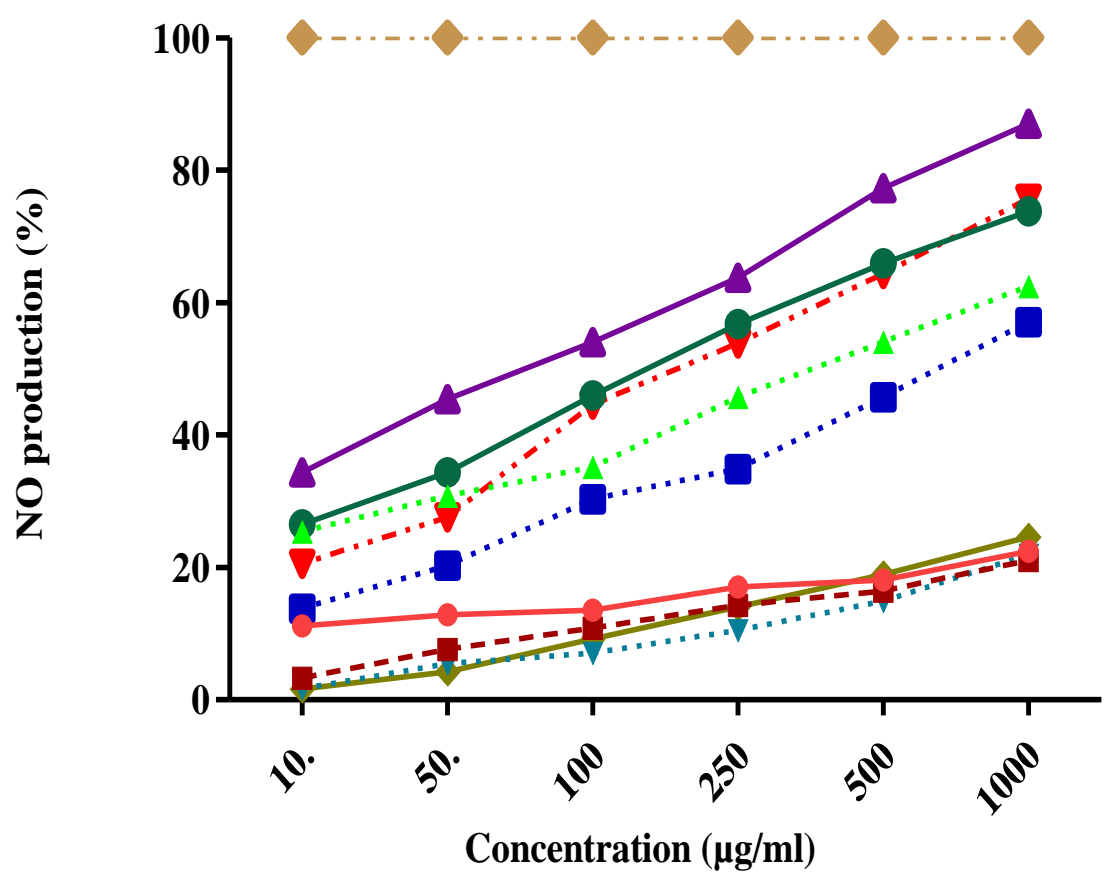

Figure 5: The effect of nine plant extracts on the production of NO in LPS-stimulated RAW 264.7 cells. Cells were treated with various plant extracts $(10-1000 \mu \mathrm{g} / \mathrm{ml})$ and stimulated with LPS $(3 \mu \mathrm{l})$ for $24 \mathrm{~h}$. NO production was measured in the cultured cell supernatant by Griess reagent. The results are expressed in percentage inhibition of NO production. The data are presented as mean \pm

S.D of triplicates results. (Significant treatment effect, $\mathrm{F}_{(45,180)}=50.57, \mathrm{p}<0.0001$; two-way ANOVA). * All plant extracts significantly different from untreated cells at all concentrations ( $\mathrm{p}<0.0001$, Bonferroni posttest), except Euclea crispa at 500 and $1000 \mu \mathrm{g} / \mathrm{ml}$, Euclea natalensis at 100, 250, and $500 \mu \mathrm{g} / \mathrm{ml}$, and Ziziphus mucronata (L) and Ziziphus mucronata (F) at $100 \mu \mathrm{g} / \mathrm{ml}$, and $250 \mu \mathrm{g} / \mathrm{ml}$ the significant difference between control, and all concentrations of plant extracts ( $\mathrm{p}<0.0001$, Bonferroni posttest). 


\section{DISCUSSION}

The purpose of this study was to evaluate the cytotoxicity and anti-inflammatory effects of Euclea crispa (leaf), Eulea natalensis (leaf), Schkuhria pinnata (leaf), Ziziphus mucronata (leaf), Ziziphus mucronata (fruits), Lippia javanica (leaf), Vernonia oligocephala (leaf), Clerodendrum myricoides (leaf), and Erythrina lysistemon (leaf) against C2C12 cells, and RAW 264.7 cells (Fig 1 to Fig 4). The cytotoxicity effect was observed in higher concentrations for all plant extracts against $\mathrm{C} 2 \mathrm{C} 12$ cells, and exhibited $\mathrm{LC}_{50}$ value of $<1000 \mu \mathrm{g} / \mathrm{ml}$. In contracts, no cytotoxicity was observed in all plant extracts against RAW 264.7 cells, and $\mathrm{LC}_{50}$ value of $>1000 \mu \mathrm{g} / \mathrm{ml}$. All plant extracts demonstrated some degree of anti-inflammatory effect (Fig 5). However, five plant extracts exhibited marked anti-inflammatory activities. These plants Clerondendrum myricoides (35\%-89\%), Lippia javanica (26\% - 77\%), Erythrina lysistemon (23\% - 76\%), Schkuhria pinnata (27\% - 65\%), and Vernonia oligocephala $(16 \%$ $-58 \%)$.

The findings of this study have shown that all plant extracts exhibited a decrease in cell viability against of $\mathrm{C} 2 \mathrm{C} 12$ cells, and this was observed only at the highest concentration of $1000 \mu \mathrm{g} / \mathrm{ml}$. The results can be interpreted that these plant extracts only shown a decrease in cell viability at the highest concentration, but it does not mean that they are toxic to the cells. None of the plant extracts exhibited cytotoxicity effects against RAW 264 cells in all concentrations used. The cell viability was observed to have a dose-response where cell viability decreases with an increase in concentration. Essentially, Alamar Blue cell viability assay was noticeable to agree with crystal violet cell viability assay. Seven plant extracts did not show any cytotoxicity effects even in the high concentrations $(1000 \mu \mathrm{g} / \mathrm{ml})$ against RAW 264.7 cells.

The results of this study were noticed to be least toxic when compared with other researchers. Euclea crispa was observed with $\mathrm{LC}_{50}$ value of $566.502 \mu \mathrm{g} / \mathrm{ml}$ in this study. In other studies, the toxicity of Euclea crispa was observed against breast cancer cells in Combretum molle (Rademana., et al 2017). The $\mathrm{IC}_{50}$ value of Euclea crispa extract was reported as low as $45.7 \mu \mathrm{g} / \mathrm{ml}$ and as high as $167.2 \mu \mathrm{g} / \mathrm{ml}$. The cytotoxicity of Euclea natalensins was observed in higher concentrations with $\mathrm{LC}_{50}$ value of 454.497 $\mu \mathrm{g} / \mathrm{ml}$. Similarly, cytotoxicity was reported on Euclea natalensis in another study where plant extracts were treated with Chang liver cells was reported cytotoxicity as low as $131.3 \mu \mathrm{g} / \mathrm{ml}$ and as high as $108.9 \mu \mathrm{g} / \mathrm{ml}$ (Ojewole, 2004). The cytotoxicity of Schkuhria pinnata with $\mathrm{LC}_{50}$ value of $206.079 \mu \mathrm{g} / \mathrm{ml}$ against $\mathrm{C} 2 \mathrm{C} 12$ cells and no toxicity was observed against RAW 264.7 cells with $\mathrm{LC}_{50}$ value of $2458.681 \mu \mathrm{g} / \mathrm{ml}$. In contracts, Kudumela., et al (2018) described $S$. pinnata as most toxic in plant extracts against Vero cells using MTT assay with $\mathrm{LC}_{50}<25.0 \mu \mathrm{g} / \mathrm{ml}$. Furthermore, studies are required to confirm the toxicity of $S$. pinnata, hence both methods used in both occasions are sensitive enough to detect cytotoxicity on plant extracts in cells (Hamid et al., 2004), since no agreement on the outcomes in both studies.

In the present study, Ziziphus mucronata did not show any cytotoxicity effects with $\mathrm{LC}_{50}$ values of $2582.656 \mu \mathrm{g} / \mathrm{ml}$ against RAW 264.7 cells, however, it was toxic against C2C12 cells with $\mathrm{LC}_{50}$ value of $150.210 \mu \mathrm{g} / \mathrm{ml}$. Previous studies have reported cytotoxicity of Ziziphus mucronata with $\mathrm{LC}_{50}$ value ranged from $0.10 \mu \mathrm{g} / \mathrm{ml}$ to $0.22 \mu \mathrm{g} / \mathrm{ml}$ against Bovine dermis and Vero cells (Mongalo et al., 2018). In other studies, no cytotoxicity was reported for $Z$. mucronata in RAW 264.7 cells with $\mathrm{LC}_{50}$ value as low as $>50 \mu \mathrm{g} / \mathrm{ml}$. Furthermore, selective cytotoxicity was reported for Z . mucronata against U937 cancer to be $>500 \mu \mathrm{g} / \mathrm{ml}$ (Sigidi et al., 2016). In the present study, cytotoxicity was observed for Lippia javanica with $\mathrm{LC}_{50}$ values value of 185.906 $\mu \mathrm{g} / \mathrm{ml}$ against $\mathrm{C} 2 \mathrm{C} 12$ cells, and interesting no cytotoxicity was observed against RAW 264.7 cells with LC $_{50}$ value of 2477.176 $\mu \mathrm{g} / \mathrm{ml}$. Makhafola et al., (2019) confirmed our findings of $L$. javanica on liver cells with reported $\mathrm{LC}_{50}$ value $>1000 \mu \mathrm{g} / \mathrm{ml}$, of which is in agreement with RAW 2643.7 cells. The cytotoxicity effects were observed for Vernonia oligocephala against both cells with $\mathrm{LC}_{50}$ value $<250 \mu \mathrm{g} / \mathrm{ml}$. Furthermore, nothing has been reported in the literature on $V$. oligocephala cytotoxicity. The cytotoxicity effects were observed for Clerodendrum myricoides against both cells $\mathrm{LC}_{50}$ values $<650 \mu \mathrm{g} / \mathrm{ml}$. In other studies, reported $C$. myricoides cytotoxicity of $\mathrm{IC}_{50}$ value below $1 \mu \mathrm{g} / \mathrm{ml}$ against breast cancer cells (Tuasha et al., 2019). In contracts to the present study, Kamanja et al., (2018), reported cytotoxicity levels showing high $\mathrm{LC}_{50}<1000 \mu \mathrm{g} / \mathrm{ml}$ in chloroform extracts and lower $\mathrm{LC}_{50}(>1000 \mu \mathrm{g} / \mathrm{ml})$ in methanol extracts. Essentially, the toxicity of this plant depends on the solvent used, however, it has been noticeable to be safe for use in traditional medicine space (Kamanja et al., 2018). No cytotoxicity was observed for Erythrina lysistemon with noticeable $\mathrm{LC}_{50}$ values ranged from $773.427 \mu \mathrm{g} / \mathrm{ml}$ to $1213.327 \mu \mathrm{g} / \mathrm{ml}$. In other studies, cytotoxicity was reported for E. lysistemon with $\mathrm{IC}_{50}$ value below $100 \mu \mathrm{g} / \mathrm{ml}$ using MTT against C3A human liver cells (Mukandiwa et al., 2012). This plant extract has been observed to have contradiction results and further animal studies can validate its toxicity, which will confirm its medicinal use.

In addition to this, the ability of plant extracts to inhibit NO production by RAW 264.7 cells - stimulated with LPS was assessed (Fig 5). All plant extracts exhibited a degree of NO inhibition effects against all concentrations used. Essentially, inhibition of NO production was observed for Euclea crispa at 500 and $1000 \mu \mathrm{g} / \mathrm{ml}$ with $\mathrm{IC}_{50}$ value of $1242.366 \mu \mathrm{g} / \mathrm{ml}$, Euclea natalensis at 100,250 , and $500 \mu \mathrm{g} / \mathrm{ml}$ with $\mathrm{IC}_{50}$ value of 1588.573 $\mu \mathrm{g} / \mathrm{ml}$, Ziziphus mucronata (L) with $\mathrm{IC}_{50}$ value of 11949.000 $\mu \mathrm{g} / \mathrm{ml}$, and Ziziphus mucronata (F) at $100 \mu \mathrm{g} / \mathrm{ml}$, and $250 \mu \mathrm{g} / \mathrm{ml}$ with $\mathrm{IC}_{50}$ value of $499.600 \mu \mathrm{g} / \mathrm{ml}$. Furthermore, Clerondendrum myricoides, Lippia javanica, Erythrina lysistemon, Schkuhria pinnata, and Vernonia oligocephala were observed to inhibit NO production at higher concentrations $(100-1000 \mu \mathrm{g} / \mathrm{ml})$ LPS induced RAW 264.7 cells. The $\mathrm{IC}_{50}$ values ranged from 707,335, 177.902, 264.287, 348.859, and $2634.965 \mu \mathrm{g} / \mathrm{ml}$, resepectively against RAW 264.7 cells.

Interestingly, the inhibition NO production was observed for Eucela crispa which ranged from 17 to $25 \%$ and more prominent in higher concentrations $(100,250$, and $500 \mu \mathrm{g} / \mathrm{ml})$, and IC $_{50}$ value was noted to be $124.366 \mu \mathrm{g} / \mathrm{ml}$. Although, no study in the literature to substantiate these findings, the results validate the use of this plant in traditional medicinal practice. The uses includes treatment stomach disorders, measles, coughs, constipation, remedy for diabetes, and also prevents rheumatisms and epilepsy (Raimondo et al., 2009; Deutschländer et al., (2009). Similarly, Euclea natalensis was observed to have a similar inhibition effect as E.crispa. The NO inhibition ranged from $4 \%$ to $23 \%$ which was more effective in higher concentrations $(100$, 250 , and $500 \mu \mathrm{g} / \mathrm{ml}$ ), and $\mathrm{IC}_{50}$ value of $1588.573 \mu \mathrm{g} / \mathrm{ml}$ was 
observed. No other studies have been reported for inhibition of NO production by $E$. natalensis. These study results validate E.natalensis for conventional medicinal applications. This plant has been used for snakebite cure, hypertension, vomiting, measles, roundworms, stomach problems, toothache, venereal diseases, and injuries (Maroyi, 2017).

Schkuhria pinnata was also observed to be effective at higher concentrations with inhibition of NO production from $27 \%$ to $65 \%$ at 100 to $1000 \mu \mathrm{g} / \mathrm{ml}$ with $\mathrm{IC}_{50}$ value of $348.859 \mu \mathrm{g} / \mathrm{ml}$. In another study, a similar pattern was reported whereby inhibition was more effective in higher concentrations, which ranged from $64 \%$ to $98 \%$ respectively (Kudumela et al., 2018). A good inhibition of NO production was observed for Ziziphus mucronata which ranged from $3 \%$ to $26 \%$ with $\mathrm{IC}_{50}$ value of 11949.000 $\mu \mathrm{g} / \mathrm{ml}$. In contracts, $Z$. mucronata the inhibition of $\mathrm{NO}$ production was reported at $150 \%$ at $\mathrm{IC}_{50}$ value of $50 \mu \mathrm{g} / \mathrm{ml}$ (Sigidi et al., 2016).

The inhibition of NO production for Lippia javanica was also observed to ranged from $26 \%$ to $77 \%$ with $\mathrm{IC}_{50}$ value measured at $177.902 \mu \mathrm{g} / \mathrm{ml}$. Dzoyem and Eloff, (2014) reported on the inhibition of NO production was of $L$. javanica which was reported at $97 \%$ for $25 \mu \mathrm{g} / \mathrm{ml}$ with $\mathrm{IC}_{50}$ value of $18 \mu \mathrm{g} / \mathrm{ml}$. The results validate the use of L. javanica in traditional medicine uses such as herbal tea and ethnomedicinal applications for (in descending order of importance) colds, cough, fever or malaria, wounds, repelling mosquitos, diarrhea, chest pains, bronchitis, and asthma (Maroyi, 2017).

Essentially, NO inhibition was observed for Vernonia oligocephala to be effective in higher concentrations, and ranged from $26 \%$ to $58 \%$ and $\mathrm{IC}_{50}$ value noticeable to be $2634.965 \mu \mathrm{g} / \mathrm{ml}$. No other studies have been found to substantiate these finding and to the best of our knowledge, these findings complement the use of this plant in traditional medicine practice. The medicinal use includes treatment of abdominal pain, colic, and other complaints as well as to drive away hailstorms. In addition to this, used as a remedy to treat mild forms of diabetes (Amusan et al., 2017). The inhibition of NO production ranged from $35 \%$ to $89 \%$ for Clerodendrum myricoides was only observed in higher concentrations $(250-1000 \mu \mathrm{g} / \mathrm{ml})$ with $\mathrm{IC}_{50}$ value of 707.335 $\mu \mathrm{g} / \mathrm{ml}$. Similarly, inhibition of NO production ranged from $23 \%$ to $76 \%$ for Erythrina lysistemon was only prominent at higher concentrations $(250-1000 \mu \mathrm{g} / \mathrm{ml})$ with $\mathrm{IC}_{50}$ value of 264.287 $\mu \mathrm{g} / \mathrm{ml}$.

The anti-inflammatory effects may be associated with antioxidant properties. Interestingly, these plant extracts exhibited ROS inhibition activity in high concentrations. It is imperative to further evaluate anti-inflammatory efficacy in vivo as to substantiate these findings and to ensure that is safe for human use. Inflammation has been implicated to be associated with the pathogenesis of conditions such as infections, arthritis, type 2 diabetes mellitus, obesity and cancer (Johnson et al., 2012; Maconi et al., 2014). Non-steroidal anti-inflammatory drugs (NSAIDs) are commonly prescribed for pain and inflammation conditions (Yuan et al., 2006). Unfortunately, NSAIDs have been reported to be associated with adverse side effects such as gastrointestinal bleeding and suppressed the function of the immune system (Hougee, 2008). They have been increased research on the use of natural-source concerning antiinflammatory properties because it has been reported to have fewer side effects as opposed to NSAIDs (Maroon et al., 2010; Pelkonen et al., 2014; Nondo et al., 2015). Medicinal plants consist of major natural bioactive compounds that attribute to scavenging ROS such as antioxidants (Singh., et al 2016; Engwa, 2018). In this study, it can be seen that plant extracts possess protective effects on cells. The results support the uses of these medicinal plants in African traditional, complementary and alternative medicine practice (Nkala., et al 2019a). Essentially, four plant extracts that demonstrated promising anti-inflammatory effects which can be a good candidate for the treatment or management of inflammatory diseases. Even though all plant species in this study demonstrated a degree of cytotoxicity against C2C12 cells in higher concentrations. Similarly, these plants exhibited anti-inflammatory abilities, of which counteract for their cytotoxicity observed against $\mathrm{C} 2 \mathrm{C} 12$.

The findings of the current study complement our previous review of the uses of selected medicinal plants by healers (Nkala et al., 2019a). To this date, the selected South African plants have been validated for minimum inhibition concentration (MIC) and minimum bactericidal concentration (MBC) (Nkala et al., 2019b), and most importantly, they have been recently confirmed for being none cytotoxicity against RAW 264.7 cells, however, toxicity was observed against $\mathrm{C} 2 \mathrm{C} 12$ in higher concentrations. Furthermore, they have been observed to possess anti-inflammatory potential.

\section{CONCLUSION}

None of the selected South African plants demonstrated cytotoxicity effects in RAW 264.7 cells. The observed cytotoxicity effects were against $\mathrm{C} 2 \mathrm{C} 12$ cells in higher concentrations. Importantly, this will need further validation in animal studies to confirm these findings. Furthermore, the results demonstrated these selected South African plants exhibited a degree of anti-inflammatory activity in LPS-induced RAW 264.7 cells. Therefore, the findings suggest that Clerondendrum myricoides, Lippia javanica, Erythrina lysistemon, Schkuhria pinnata, and Vernonia oligocephala can be a promising therapeutic agent for inflammatory diseases. Further studies are required to evaluate these plant extracts for antioxidants and antidiabetic potential.

\section{CONFLICT OF INTEREST}

The authors declare that they do not have any conflict concerning the publication of this paper.

\section{ACKNOWLEDGMENT}

We thank the College Health Sciences Scholarship Grant at the University of KwaZulu-Natal, Institute of Traditional Knowledge and Traditional Medicine at the Vaal University of Technology, the National Research Foundation and Thuthuka grant for the financial support received towards this study. $\mathrm{Dr}$ Cornelius Ssemkalu is thanks for allowing us to use his tissue culture laboratory at the Vaal University of Technology. Finally, Mr. Gary Mohlala from Vaal University of Technology tissue culture laboratory is thanks for providing technical assistance 
towards this work. Furthermore, we express our sincere gratitude to Prof Vivienne Russel for proofreading this manuscript.

\section{REFERENCES}

[1] Al-Nasiry. S., Geusens, N., Hanssens, M., Luyten, C., Pijnenborg, R. (2007). "The use of Alamar Blue assay for quantitative analysis of viability, migration and invasion of choriocarcinoma cells." Human Reproduction 22 (5): 1304-1309.

[2] Amusan, O. O. G., Sukati, N.A., Dlamini, P.S., Sibandze, F.G. (2017). "Some Swazi phytomedicines and their constituents." African Journal of Biotechnology 6 (3): 267-272.

[3] Arika, W. M., Ogola P.E., Abdirahman, Y.A., Mawia, A.M., Wambua, F.K., Nyamai, D.W., Kiboi, N.G., Wambani, J.R., Njagi, S.M., Rachuonyo, H.O., Muchori, A.N., Lagat, R.C., Agyirifo, D.S., Ngugi, M.P., Njagi, E.N.M (2016). "In Vivo Safety of Aqueous Leaf Extract of Lippia javanica in Mice Models." Biochemistry and Physiology 5(1): 1-9.

[4] Ayupova, D., Dobhal, G., Laufersky, G., Nann, T., Goreham, R.V., (2019). "An In Vitro Investigation of Cytotoxic Effects of InP/Zns Quantum Dots with Different Surface Chemistries." Nanomaterials 22(9): 1-13.

[5] Berghaus, L. J., James, N., Moore, D.J., Hurley, M.L., Vandenplas, B.P., Fortes, B. P., Wolfert, M. A., Boons, G.J. (2010). "Innate immune responses of primary murine macrophage-lineage cells and RAW 264.7 cells to ligands of Toll-like receptors 2, 3, and 4." Comparative immunology, microbiology and infectious diseases 33 (5): 443-454.

[6] Beseni, B. K., Matsebatlela, T. M., Bagla, V. P., Njanje, I., Poopedi, K., Mbazima, V., Mampuru, L., Mokgotho, M. P. (2019). "Potential Antiglycation and Hypoglycaemic Effects of Toona ciliata M. Roem. and Schkuhria pinnata Lam. Thell. Crude Extracts in Differentiated C2C12 Cells." Evidence-Based Complementary and Alternative Medicine 1-12.

[7] Burattini, S., Ferri, P., Battistelli, M., Curci, R., Luchetti, F., Falcieri, E (2009). "C2C12 murine myoblasts as a model of skeletal muscle development: morpho-functional characterization." European Journal of Histochemistry 48: 223-234.

[8] Bussmann, R. W., Sharon, D., Daiz, D.P (2008). "Peruvian plants canchalagua (Schkuhria pinnata (Lam.) Kuntze), hercampuri (Gentianella alborosea (Gilg.) Fabris), and corpus way (Gentianella bicolor (Wedd.) J. Pringle) prove to be effective in the treatment of acne." Arnaldoa 15 (1): 149152.

[9] Deutschländer, M. S., Lall, N., van de Venter, M (2009). "Plant species used in the treatment of diabetes by South African traditional healers: An inventory." Pharmaceutical Biology 47(4): 348-365.

[10] Dzoyem, J. P. and Eloff. J.N (2014). "Anti-inflammatory, anticholinesterase and antioxidant activity of leaf extracts of twelve plants used traditionally to alleviate pain and inflammation in South Africa." Journal of Ethnopharmacology 160: 194-201.

[11] Engwa, G. A. (2018). Free Radicals and the Role of Plant Phytochemicals as Antioxidants Against Oxidative Stress-Related Diseases. Chapter 4 Phytochemicals - Source of Antioxidants and Role in Disease Prevention. Viewed on 24th 2019, http://dx.doi.org/10.5772/intechopen.76719.

[12] Farag, M. A., Mekky, H., El-Masry, S (2016). "Metabolomics driven analysis of Erythrina lysistemon cell suspension culture in response to methyl jasmonate elicitation." Journal of Advanced Research 7: 681-689.

[13] Feoktisova, M., Geserick, P., Leverkus, M. (2016). Crystal violet assay for cultured cells., Cold Spring Protocols.

[14] Fuentes, A.L., Mills, L., Vapenik, J., Sigola, L. (2014). "Lipopolysaccharidemediated enhancement of zymosan phagocytosis by RAW 264.7 macrophages is independent of opsonins, laminarin, mannan, and complement receptor 3." Journal of Surgical Research 189(2): 304-312.

[15] Girgis, C. M., Clifton-Bligh, R.J., Mokbel, N., Cheng, K. and Gunton, J.E (2013). "Vitamin D signaling regulates proliferation, differentiation, and myotube size in C2C12 skeletal muscle cells." Endocrinology 155: 347-357

[16] Hamid, R., Rotshteyn, Y., Rabadi, L., Parikh, R., Bullock, P. (2004). "Comparison of Alamar Blue and MTT assays for high throughput screening." Toxicology in vitro: an international journal published in association with BIBRA 18: 703-710.3

[17] Harbilas, D., Martineau, L. C., Harris, C. S., Adeyiwola-Spoor, D. C., Saleem, A., Lambert, J., Caves, D., Johns, T., Prentki, M., Cuerrier, A.,
Arnason, J. T., Bennett, S. A., Haddad, P. (2009). "Evaluation of the antidiabetic potential of selected medicinal plant extracts from the Canadian boreal forest used to treat symptoms of diabetes: part II." Canadian Journal of Physiology and Pharmacology 87(6): 479-492.

[18] Hougee, S. (2008). Plant- derived modulators of inflammation and cartilage metabolism The Netherlands, Utrecht University. PhD.

[19] Hyejin, L., Sang-Jin, L., Gyu-Un, B., Nam-In, B., Jae-Ha, R. (2017). "Canadine from Corydalis turtschaninovii Stimulates Myoblast Differentiation and Protects against Myotube Atrophy." International Journal of Molecular Sciences 18:1-13.

[20] Ibrahim, M. A. and Islama, S. (2017). "Effects of butanol fraction of Ziziphus mucronata root ethanol extract on glucose homeostasis, serum insulin and other diabetes-related parameters in a murine model for type 2 diabetes." Pharmaceutical Biology 55(1): 416-422.

[21] Javad, M., Vakili, T., Hadinedoushan, H., Ali, K. (2011). "C2C12 cell line is a good model to explore the effects of herbal extracts on muscular GLUT4 metabolism." Clinical Biochemistry 44(13): S332 - S336.

[22] Jo, W.-S., Choi, Y.J., Kim, H.J., Nam, B.H., Lee, G.A., Seo, S.Y., Lee, S.W., Jeong, M.H. (2010). "Methanolic extract of Asterina pectinifera inhibits LPSinduced inflammatory mediators in murine macrophage." Toxicology Research 26(1): 37-46.

[23] Johnson, A. R., Milner, J.J., Makowski, L (2012). "The inflammation highway: metabolism accelerates inflammatory traffic in obesity " Immunological Review 249(1): 218-238.

[24] Kamanja, I. T., Mbaria, J.M., Gathumbi, P.K., Mbaabu, M., John, D.K., Kiama, S.G. (2018). "Cytotoxicity of selected medicinal plants extracts using the brine shrimp lethality assay from Samburu county, Kenya." The Journal of Medical Research 4(5): 249-255.

[25] Kamtchueng, M. O., Balyan, R., Mouokeu, R. S., Tume, C., Banerjee, C., Singh, C.A., Oumar, M., Kuiate, J. R., (2017). "Anti-Inflammatory Activity of Methanol Extract and Fractions from Alchemilla kiwuensis Engl. on LPS Activated Macrophages." International Journal of Pharmacognosy and Phytochemical Research 9(4): 473-481.

[26] Kaur, G. and Dufour, J.M. (2012). "Cell lines: Valuable tools or useless artifacts." Spermatogenesis 2(1): 1-5.

[27] Kudumela, R. G., McGaw, L.J., Masoko, P (2018). "Antibacterial interactions, anti-inflammatory and cytotoxic effects of four medicinal plant species." BMC Complementary and Alternative Medicine 18(199): 1-7.

[28] Lee, C. J., Chen, L.G., Liang, W.L., Wanga, C.C (2010). "Anti-inflammatory effects of Punica granatum Linne in vitro and in vivo." Food Chemistry Journal 118: 315-322.

[29] Lee, S. C., Kwon, Y.W., Park, J.Y., Park, S., Lee, J.H., Park, S.G. (2017) "Antioxidant and Anti-Inflammatory Effects of Herbal Formula SC-E3 in Lipopolysaccharide-Stimulated RAW 264.7 Macrophages." Evidence-based Complementary and Alternative Medicine 1-13

[30] Lim, Y., Park, J.W., Kwon, O.K., Lee, J.W., Lee, H.S., Lee, S., Choi, S., Li, W., Jin, H., Han, S.B., Ahn, K.S. (2018). "Anti-inflammatory effects of a methanolic extract of Castanea seguinii Dode in LPS-induced RAW264.7 macrophage cells." International Journal of Molecular Medicine 41(1): 391398.

[31] Maconi, G., Furfaro, F., Scieurti, R., Bezzi, C., Ardizzone, S., de Franchis, R (2014). "Glucose intolerance and diabetes mellitus in ulcerative colitis: Pathogenetic and therapeutic implications." World Journal of Gastroenterology 20 (13): 3507-3515.

[32] Makhafola, M. A., Middleton, L., Olivier, M. T., Olaokun, O. O. (2019) "Cytotoxic and Antibacterial Activity of Selected Medicinal Plants used in South African Traditional Medicine." Asian Journal of Chemistry 31(11): 2623-2627.

[33] Maroon, J. C., Bost, J.W., Maroon, A (2010). "Natural anti-inflammatory agents for pain relief." Surgical Neurology International 1(80): 1-16.

[34] Maroyi, A. (2017). "Review of Ethnomedicinal Uses, Phytochemistry and Pharmacological Properties of Euclea natalensis A.DC." Molecules 22(12): $1-16$.

[35] Mongalo, N. I., Dikhoba, P. M., Soyingbe, S. O., Makhafola, T. J. (2018) "Antifungal, anti-oxidant activity and cytotoxicity of South African medicinal plants against mycotoxigenic fungi." Heliyon 4(11): 1-23.

[36] Morissette, M. R., Cook, S.A., Buranasombati, C., Rosenberg, M.A., Rosenzweig, A (2009). "Myostatin inhibits IGF-I-induced myotube hypertrophy through Akt." American Journal of Physiology - Cell Physiology 297: 1124-1132. 
[37] Mukandiwa, L., McGawa, L., Eloff, J.N., Naidoo, V (2012). "Extracts of four plant species used traditionally to treat myiasis influence pupation rate, pupal mass and adult blowfly emergence of Lucilia cuprina and Chrysomya marginalis (Diptera: Calliphoridae)." Journal of Ethnopharmacology 143(3): 812-818.

[38] Musso, F., Lincor, D., Vasconsuelo, A., Pronsato, L., Faraoni, B., Milanesi, L. (2019). "Adverse Effects in Skeletal Muscle Following the Medicinal Use of Nicotiana glauca." Biological and Pharmaceutical Bulletin 42(5): 671679.

[39] Nkala, B. A., Mbongwa, H.P., Qwebani-Ogunleye, T (2019a). "A Review on Selected African Medicinal Plants with Effectiveness in the Management of Type II Diabetes Mellitus." Acta Scientific Pharmaceutical Sciences 3 (8): 2581-5423.

[40] Nkala, B. A., Mbongwa, H.P., Qwebani-Ogunleye, T (2019b). "The in vitro evaluation of some South African plant extracts for minimum inhibition concentration and minimum bactericidal concentration against selected bacterial strains." International Journal of Scientific and Research Publications 9(7): 995-1004.

[41] Nondo, R. S. O., Moshi, M.J., Erasto, P., Zofou, D., Njouendou, A.J., Wanji, S., Ngemenya, M.N., Kidukuli, A.W., Masimba, P.J., Titanji, V.P.K (2015). "Evaluation of the cytotoxic activity of extracts from medicinal plants used for the treatment of malaria in Kagera and Lindi regions, Tanzania." Journal of Applied Pharmaceutical Science 5(4): 007-012

[42] Ojewole, O. J. A. (2004). "Indigenous plants and schistosomiasis control in south africa:molluscicidal activity of some Zulu medicinal plants." Boletín Latinoamericano y del Caribe de Plantas Medicinales y Aromáticas 3: 8-22.

[43] Padmanabha, R.A., and Kaiser, J. (2011). "Pharmacological evaluation of herbal extracts for their in vitro hypoglycaemic activity." International Journal of Phytopharmacology 2(1): 15-21.

[44] Pan, S. Y., Zhou, S.F., Gao, S.H., Yu, Z.L., Zhang, S.F., Tang, M.K., Sun, J.N., Ma, D.L., Han, D.F., Fong, W.F., Ko, K.M (2013). "New Perspectives on How to Discover Drugs from Herbal Medicines: CAM's Outstanding Contribution to Modern Therapeutics." Hindawi Publishing Corporation Evidence-Based Complementary and Alternative Medicine 1-25.

[45] Pelkonen, O., Xu, Q., Fan, T. P. (2014). "Why is Research on Herbal Medicinal Products Important and How Can We Improve Its Quality?" Journal of Traditional and Complementary Medicine 4(1): 1-7.

[46] Rademana, S., Anantharajub, P.G., Rao V., Madhunapantulab, S., Lalla, N (2017). " The anti-proliferative and antioxidant activity of four indigenous South African plants." African Journal of Traditional, Complementary and Alternative Medicines 16(1): 13-23.

[47] Raimondo, D., Von Staden, L., Foden, W., Victor, J.E., Helme, N.A., Turner, R.C., Kamundi, D.A. and Manyama, P.A (2009). " Red List of South African plants. Strelitzia 25. Pretoria, South African National Biodiversity Institute."

[48] Razali, F. N., Ismail, A., Abidin, N., Zainal, S., Adawiyah, S. (2014). "Stimulatory effects of polysaccharide fraction from Solanum nigrum on RAW 264.7 murine macrophage cells." PLoS One 9(10): e108988-e108988.

[49] Sigidi, M. T., Anokwuru, C. P., Zininga, T., Tshisikhawe, M. P., Shonhai, A., Ramaite, I. D.I., Traoré, A. N., Potgieter, N. (2016). "Comparative in vitro cytotoxic, anti-inflammatory and anti-microbiological activities of two indigenous Venda medicinal plants." Translational Medicine Communications 1-9.

[50] Singh, A., Singh, S., Prasad, M.S. (2016). "Role of Medicinal Plants for Health Perspective: Special Reference to Antioxidant Potential." Journal of Chemical Biology and Therapeutics 01(02): 1-5.
[51] Sofowora, A., Ogunbodede, E., Onayade, A (2013). " The role and place of medicinal plants in the strategies for disease prevention." African Journal of Traditional, Complementary and Alternative Medicines 10(5): 210-229.

[52] Soonthornsit, N., Pitaksutheepong, C., Hemstapat, W., Utaisincharoen, P., Pitaksuteepong, T. (2017). "In Vitro Anti-Inflammatory Activity of Morus alba L. Stem Extract in LPS-Stimulated RAW 264.7 Cells." Evidence-Based Complementary and Alternative Medicine 1-8.

[53] Soromou, L. W., Zhang, Z., Li, R., Chen, N., Guo, W., Huo, M., Guan, S., Lu, J., Deng, X. (2012). "Regulation of Inflammatory Cytokines in Lipopolysaccharide-Stimulated RAW 264.7 Murine Macrophage by 7-OMethyl-naringenin." Molecules 17(3): 3574-3585

[54] Taciak, B., Białasek, M., Braniewska, A., Sas, Z., Sawicka, P., Kiraga, Ł., Rygiel, T., Król, M. (2018). "Evaluation of phenotypic and functional stability of RAW 264.7 cell line through serial passages." PLoS One 13(6): e0198943.

[55] Tuasha, N., Seifu, D., Gadisa, E, Petros, B., Stina, O. (2019). "Cytotoxicity of selected Ethiopian medicinal plants used in traditional breast cancer treatment against breast-derived cell lines." Journal of Medicinal Plants Research 13(9): 188-198.

[56] van Huyssteen, M., Milne, P.J., Campbell, E.E., van de Venter, M. (2011) "Antidiabetic and cytotoxicity screening of five medicinal plants used by traditional practitioners in the Nelson Mandela Metropole, South African." African Journal of Traditional, Complementary and Alternative Medicines 8(2): $150-158$

[57] Van Wyk, B.-E. (2011). "The potential of South African plants in the development of new medicinal products." South African Journal of Botany. 77: 812-829

[58] Yaffe, D., and Saxel, O (1977). "Serial passaging and differentiation of myogenic cells isolated from dystrophic mouse muscle." Nature 270: 725 727.

[59] York, T. (2012). An ethnopharmacological study of plants used for treating respiratory infections in rural Maputal and. KwaDlangezwa, University of Zululand. Masters.

[60] Yuan, G., Wahlqvist, M.L., He, G., Yang, M., Li, D (2006). "Natural products and anti-inflammatory activity." Asia Pacific Journal of Clinical Nutrition 15(2): 143-152.

[61] Yuan, H., Ma, Q. Ye, L., Piao, G. (2016). "The Traditional Medicine and Modern Medicine from Natural Products." Molecules 21(559): 1-18.

\section{AUTHORS}

First Author - Nkala, B.A, Department of Human Physiology, School of Laboratory Medicine and Medical Sciences, College of Health Sciences, University of KwaZulu-Natal, Durban, 4001, South Africa, Email: bee.nkala81@gmail.com (Nkala, B.A.) Second Author - Mbongwa, H.P, Department of Human Physiology, School of Laboratory Medicine and Medical Sciences, College of Health Sciences, University of KwaZuluNatal, Durban, 4001, South Africa

Third Author - Qwebani-Ogunleye, T, Institute of Traditional Medicine and Traditional Knowledge, Vaal University of Technology Science and Technology Park, 5 Moshoeshoe Road, Sebokeng, 1911, South Africa. 